Bingöl Üniversitesi
Iktisadi ve İdari Bilimler Fakültesi Dergisi
Bingol University
Journal of Economics and Administrative Sciences
Cilt/Volume: 5, Say1/Issue: 2
Y1l/Year: 2021, s. 215-240
DOI: 10.33399/biibfad.879116
ISSN: 2651-3234/E-ISSN: 2651-3307
Bingöl/Türkiye
Makale Bilgisi/Article Info
Geliş/Received: $12.02 .2021 \quad$ Kabul/ Accepted: 06.10 .2021

\title{
CATASTROPHIC BEASTS AND HOW TO STUDY THEM: RESEARCHING ILLICIT FINANCIAL ACTIVITIES IN INTERNATIONAL POLITICAL ECONOMY
}

\author{
Felaket Canavarları ve Bunları Nasıl Çalışmalı: \\ Uluslararası Politik Ekonomide Yasadışı Finansal Faaliyetleri \\ Araştırmak
}

Ahmet ATEŞ*

\begin{abstract}
There is relatively less attention to illicit financial activities in the International Political Economy (IPE) studies, and it is quite ambiguous how to study these illicit activities. American IPE's materialistic nature and state-centric approach miss essential features/relations of these illicit activities because they are neither materialistic nor state-centric. On the other hand, the British school is more suitable than American IPE because of its inclusive and multidisciplinary research and its engagement with realworld situations. However, its normative agenda and its motivation to judge rather than explain can be tricky in researching illicit activities. I argue that Constructivist IPE is the most suitable school because of its dynamism and concepts, namely meaning, cognition, uncertainty, and subjectivity. Utilizing these four concepts, researchers can conduct more detailed and more fruitful analyses regarding illicit financial activities. Showing why the Constructivist IPE is the most suitable school of IPE to research with a case study on tax havens' status after 9/11, I assert that there should be more research in illicit financial activities in the IPE studies.
\end{abstract}

\footnotetext{
* Ph.D., Faculty Member, Iğdır University, Faculty of Economics and Administrative Sciences, Department of Political Science and International Relations, ahmet.ates@igdir.edu.tr, ORCID: https://orcid.org/0000-0001-5184-7701
} 
Keywords: International Political Economy, terrorism, tax havens, 9/11 attacks, hawala system

Jel Code: E26; H56; K42

Öz

Uluslararası Politik Ekonomi (IPE) çalışmalarında yasadışı finansal faaliyetlere nispeten daha az ilgi vardır ve bu yasa dışı faaliyetlerin nasıl inceleneceği oldukça belirsizdir. Amerikan ekolünün materyalist doğası ve devlet merkezli yaklaşımı bu yasa dışı faaliyetlerin temel özelliklerini/ilişkilerini gözden kaçırmaktadır. Öte yandan İngiliz okulu, kapsayıcı olması, multidisipliner yönü ve dünya üzerindeki sorunları konu edinmesi nedeniyle Amerikan ekolünden daha uygundur. Bununla birlikte, normatif gündemi ve açıklamaktan ziyade yargılama motivasyonu sebebiyle, yasa dışı faaliyetlerin araştırılması hususunda yanıltıcı olabilmektedir. Bu makalede, Konstrüktivist ekolün dinamik olması ve temel dört kavramı sebebiyle yasa dışı finansal faaliyetleri araştırma konusunda en uygun ekol olduğu savunulmaktadır. Bu ekolden yararlanan araştırmacıların bu dört kavramı kullanarak yasa dışı finansal faaliyetlerle ilgili daha detaylı ve daha verimli analizler yapabileceği öne sürülmektedir. Konstrüktivist ekolün bu tarz faaliyetlerin incelenmesinde neden daha başarılı olduğu 11 Eylül'den sonra vergi cennetlerinin statüsüne ilişkin bir vaka çalışması ile ispatlanmış ve Uluslararası Politik Ekonomi çalışmalarının yasadışı finansal faaliyetlere daha çok odaklanmasının gerekliliği belirtilmiştir.

Anahtar Kelimeler: Uluslararası Politik Ekonomi, terörizm, vergi cennetleri, 11 Eylül saldırıları, Havale sistemi

Jel Kodu: E26; H56; K42

\section{Introduction}

In the 2016 movie Fantastic Beasts and How to Find Them, Newt Scamander participates in a global excursion to find and document magical creatures in 1926. Through his journey, he uses specific methods to identify and catch the fantastic beasts. It is possible to argue that beasts do not only belong to the movie's magical world but also exist in the real world with different shapes and probably not as fantastic as in the movie. Terrorist financing, money laundering, and tax havens are catastrophic beasts of the international political and economic world. Not only their very nature of harming the society but 
also their adverse effects on financial balance is crucial. However, there is significantly less scholarly attention to these beasts. In other words, International Political Economy (IPE) studies do not have an interest in researching illicit financial activities as much as they should. Since there is relatively less attention to illicit financial activities in the IPE studies, it is mostly ambiguous how to study these illicit activities.

Existing literature consists of either security-focused research, which is not mainly related to economic perspective and background of the issue or narrowly focused on countermeasures of illicit financial activities and mainly focuses on terrorist financing. Hence, it is imperative to find more suitable approaches to research illicit financial activities. These catastrophic beasts should be studied more in IPE studies with more suitable methods. In that manner, I argue that Constructivist IPE is the most suitable approach to research illicit financial activities. In order to explain why the Constructivist IPE is the most suitable approach to research illicit financial activities, I survey the literature on IPE schools and evaluate each school's approach regarding illicit financial activities. Then, I explain why the Constructivist IPE is a better way to research this issue.

In order to analyze illicit financial activities comprehensively, it is vital to be familiar with the concepts in the process. Therefore, I briefly explain the key concepts in illicit financial activities, namely, terrorism, funding terrorism, money laundering, and tax havens. Even though these four concepts have certain meanings, different scholars in the literature conceptualized these concepts variously.

The first concept is terrorism. There is no consensus on the definition of terrorism due to various terrorist organizations with different methods and aims. However, I benefit Federal Bureau of Investigation (FBI)'s definition of terrorism in this article. Per the FBI (2016), terrorism is conducting violent acts against a civilian population to influence government policies by intimidation or coercion. The second concept is funding/financing terrorism. According to the IMF (2016), terrorist funding/financing is collecting or providing funds to support terrorist activities. Freeman (2011) argues that not only for illegal activities but also for providing funds 
for terror-related organizations' legal activities are also counted as financing terrorism.

The third concept is money laundering. The IMF (2016) defines money laundering as a process of conversion or transfer of funds to disguise information of the origin of the funds and recirculate it to the economy. In other words, money laundering is a process of placement, layering, and integration of the money gained through illegal ways. The last concept is tax-havens. As terrorism, there is not a consensus on the definition of a tax haven. Shaxson (2011) defines tax havens as a place that offers financial secrecy, while Desai, Foley and Hines (2006: 513) emphasize tax havens services on tax avoidance. In other words, tax havens in this article refer to a place that offers financial secrecy and tax avoidance to its customers.

\section{Major IPE Schools}

Given the conceptualizations of the vital concepts, I turn my attention to the definition of IPE and IPE schools regarding researching illicit financial activities. Emerging in the late 1970s, IPE is an interdisciplinary field that infuses both political sciences and economics to explain global economic interactions within a political science framework (Veseth, 2002: 1-2; Al, 2005: 143-144; Walzenbach, 2016). During the last four decades, the field has gradually expanded and new approaches/schools have emerged. The debate on schools of IPE emerged in the 1990s due to the ontological differences among IPE scholars (Seabrooke and Young, 2017: 291; Farrell and Finnemore, 2009: 58). As a result of the divergence of the studies, the field divided into American and British approaches (Seabrooke and Young, 2017: 291). Beginning in the 2000s, new schools of IPE's were involved in the debate. In his remarkable book Advanced Introduction to International Political Economy, Cohen (2014) classifies the IPE schools based on geographical and methodological differences and argues that there are seven IPE schools, namely, the American school, America's Left-Out, the British school, Britain's Far-Out, Continental Europe, Latin America, and China. Agreeing with him, I believe that the most important schools of IPE are the American and British schools. 
However, I also argue that Constructivist IPE is also a major school in IPE, which he left out in his book.

The first major IPE school is American IPE, also known as mainstream IPE. American IPE focuses on sovereign states due to its state-centric ontology (Cohen, 2014: 15). Without normative considerations, this school's primary research purpose is to explain the international political economy with systemic and domestic level analyses (Maliniak and Tierney, 2009: 18-19; Cohen, 2014: 16-18). However, it is essential to note that most of the research is accumulated on the US economy and its role in the global financial environment (Germain, 2009: 97). As Cohen (2014: 27) emphasizes, this approach openly prizes objective observation and systematic evaluation of evidence and, therefore, marginalizes grander questions that cannot be quantitatively analyzed. Hence, it has been rapidly departing from analyzing real-world issues and has become a subdivision of statistics (Cohen, 2014: 33; Deciancio and Quiliconi, 2020: 258-259). In that manner, while its methodology resulted in an accumulation of research, having strict state-centrism, paying more attention to materialist particularities, and its limited focus on the US economy deter this approach's ability from explaining political-economic issues that contain non-state organizations and out of the Anglosphere.

The second major IPE school is the British school. Unlike American IPE, this approach does not prioritize any unit of analysis, and its scope is broader than the Anglosphere (Cohen, 2014: 50). Also, instead of focusing on quantifiable elements of the economy, this approach engages with social issues with a normative agenda of identifying injustice in the global economy (Cohen, 2014: 51; Hobson, 2019: 151152). In other words, research on this approach aims to identify and tackle the financial injustices to make the world a better place (Cohen, 2014: 61-64). In other words, this epistemological openness prevents the British school from accumulating a structured field (Berry, 2020: 32). Its normative aspiration enables engaging world problems beyond Anglosphere; however, its unstructured methodology and insistence on normative agenda obstruct an accumulation of analytical research. Put differently, the lack of consistent methodology creates a weakness of this approach. 
The last major IPE school is Constructivist IPE. This approach harshly criticizes the materialist perspective of American IPE and argues that nonmaterial elements also play an essential role in economies. Therefore, it argues that IPE needs to systematically engage in these nonmaterial elements' influence on financial institutions and practices (Abdelal, Blyth and Parsons, 2010: 2; Thies and Wehner, 2019: 721). This approach developed four paths to explain the international political economy: meaning, cognition, uncertainty, and subjectivity (Wang and Blyth, 2013: 1282). It is possible to argue that Constructivist IPE emerged as a reaction to American IPE and its materialist assumptions and methodology. Even though it has similar concepts with the British school of IPE, it does not have a normative agenda as the British school has. As American IPE, its purpose is to explain and understand how the international economy works rather than judging it. In other words, Constructivist IPE's strength is its ability to analyze nonmaterial issues. Therefore, compared to other schools, it is a more suitable school of IPE in studying illicit financial activities than other approaches.

\section{Researching Illicit Financial Activities in IPE}

Several different terrorist organizations with diverse backgrounds and motivations operate across the world. In some cases, motivations are ethnically oriented, whereas in other cases, they are religiously oriented. While terrorist groups differ dramatically in their organizational structure and goals, they have one thing in common: funds for planning, organizing, conducting attacks, training, propaganda, and, more importantly, surviving (Biersteker and Eckert, 2007: 4; Clunan, 2006: 570).

To provide the required funds, terrorist groups conduct financial activities, and therefore they are actors of the international political economy. On the one hand, they exploit the international financial system, formal banking and money service businesses to fund their activities. For instance, as Freeman and Ruehsen (2013) show, based on investigation records of the US Department of Treasury, Al Qaeda funded the perpetrators of 9/11 via Al-Madina Bank and its subsidiary United Credit Bank. Before the attack, roughly half of the money $\mathrm{Al}$ 
Qaeda sent to its members was transferred to the US through formal banking institutions (Freeman and Ruehsen, 2013: 18; Dean, Thompson and Keatinge, 2013: 62). Moreover, an investigation in the US in 2013 showed that Al-Shabab funds its members abroad via money business services such as MoneyGram (Freeman and Ruehsen, 2013: 12-13).

On the other hand, terrorist organizations frequently engage in criminal activities to finance their operations, particularly narcotics trafficking and illicit trade (Rudner, 2006: 44; Winer and Roule, 2002: 89). For instance, the Kosovo Liberation Army (KLA) involved in heroin trafficking during the Kosovo conflict to finance its operations (Dishman, 2001: 43) and the Taliban earned roughly 150 million USD in each year between 2000 and 2003 from the production and trafficking of narcotics (Giraldo, Trinkunas and Zellen, 2005: 8), whereas Hezbollah and Taliban not only involved in narcotic trafficking but also took part in laundering the money through banks in Switzerland and offshore centers in the Cayman Islands in the early 2000s (Ehrenfeld, 2002: 395; Levitt, 2002: 53). Likewise, a report on terrorism financing in 2016 demonstrates that while Hezbollah and the Irish Republican Army (IRA) are heavily involved in the illicit trade of tobacco products to fund their organization, Chechen rebels and the Euskadi Ta Askatasuna (ETA) are key actors in the illicit trade of electronic goods within Europe (Bindner, 2016: 2).

International crime and terrorist networks usually intersect in conflict areas and cooperate because money laundering and financing terrorism have similar methods to conceal the money's origin (Shelley, 2004: 102-103; Hardouin, 2009: 205). Also, needing to evade monitoring, they benefit from similar services such as wire transfers and alternative remittance systems (Donohue, 2006: 393). Besides, they both take advantage of using smart cards and international trade networks when they transfer their funds (Li and Schaub, 2004: 234235). In the collection or transfer of a vast sum of money, however, terrorist organizations prefer offshore financial institutions to carry out the transfer undetected (Rudner, 2010: 707; OECD, 2019: 24; Unger, 2017: 18). The leaks of Panamanian law firm Mossack Fonseca's documents in 2016, also called Panama Papers, revealed that several 
terrorist organizations have benefitted the services of offshore institutions since the early 1980s (Hira, Murata and Monson, 2019:195).

In other words, terrorist organizations launder their money in tax havens to finance their organizations and attacks. During this process, they heavily collaborate with organized crime groups. Financial liberalization and deregulation after the 1990s also help them achieve their goals and hide their illicit financial activities. These illicit financial activities take part in global finance and should be researched, and I argue that American and British schools of IPE are not suitable ways to research them.

American IPE is not suitable to research such activities because several features of these activities are not purely materialistic in their nature and definitely related to non-state organizations. A couple of examples can shed light on the incompetence of American IPE in explaining financing terrorism. For instance, G8 (Global Eight), founded as G7 in 1975, had its first interaction with terrorism in the 1978 Bonn Summit, a short statement about condemning terrorist attacks (Belelieu, 2002: 10). Later in the 1986 Tokyo Summit, it clearly promoted international cooperation against terrorism that later led to a series of meetings of foreign ministers of member states in 1995 (Belelieu, 2002: 12-13). After 9/11, however, it published a report on financing terrorism (Action Plan of Combatting of Terrorist Financing) and initiated a sanction program to counter financing terrorism (Belelieu, 2002: 15-16). Put differently, a global economic forum expanded its mission statement and played a critical role in countering financing terrorism over time. This transformation cannot be explained only by material interests and with a state-centric approach as in American IPE considering member states of the G8, the United States of America (USA) and Russian Federation particularly, sanctioned Saudi Arabia and Iraq even though they had voluminous trade relations with these states and it was against their material interests. From an American IPE perspective, member states acted irrationally in an issue related to non-state actors.

Another example is the European Union's (EU) funding of a terrorist organization, namely, the Palestine Liberation Organization 
(PLO). The PLO was founded in 1964 by the Arab League, gained observer status in the UN in 1974, and was designated a terrorist organization in 1987 by the US (Ehrenfeld, 2005: 2). It transformed to Palestinian Authority (PA) in 1993 after the Oslo Accords, which granted it relative legitimacy (Ehrenfeld, 2005: 5). The EU transferred 340.9 million euros to PA under the Euro-Mediterranean Partnership Program, also known as MEDA, between 2000 and 2001 (Ehrenfeld, 2005: 5). For some, it can be portrayed as funding terrorism by a respected international organization. These global economic activities cannot be explained by only a materialistic and state-centric approach. According to American IPE, the EU acted irrationally in the issue related to a non-state actor. They should have used these funds to advance their material interests and not fund terrorism, which is probably against their material interests.

The hawala system is another example. It is an alternative remittance system that operates outside of traditional banking, referred to as underground banking (Jost and Sandhu, 2003: 5). In other words, it is a money transfer without money movement and the inclusion of formal financial institutions (Bowers, 2008: 379). Even though the international community was well aware of the hawala system's potential abuse in money laundering, it did not regulate the alternative remittance systems until the 9/11 attacks (Bowers, 2008: 388). After it was revealed that two hawala organizations, al-Taqwa and al-Barakat, were used by Al-Qaeda to finance the 9/11 attack (Jamwal, 2002: 188; Raphaeli, 2003: 70; Abuza, 2003: 183; McCulloch and Pikering, 2005: 473), the Financial Action Task Force (FATF) issued a particular recommendation in 2004 on the hawala system. Then, states and financial actors started to hedge against it. In other words, unlike what American IPE assumes, material interests were not fixed or taken for granted and transformed after 9/11.

The last example is the US's funding and arming of a terrorist group, namely, The People's Protection Units (YPG). YPG is an offshoot of another terrorist organization Kurdistan Labor Party (PKK) (Stein and Foley, 2016). The PKK was declared a terrorist organization by the EU in 2002 and by the US in 2004 (Roth and Sever, 2007: 901). On the other hand, Turkey is a NATO ally and one of the US's most 
important political partners in the region. Despite Turkey's strong objection, the US has been funding and arming the YPG for the last seven years to counter the Islamic State of Iraq and Sham (ISIS). Per American IPE, the US should not have funded the YPG because it worsens its relationship with a crucial ally and its material interests. Again, focusing strictly on material interests and having a state-centric approach does not provide a fruitful analysis in researching illicit financial activities.

Given the American school of IPE's failure to explain and research illicit financial activities, I turn my attention to the British school of IPE. It can be argued that the British school is more suitable than the American IPE in terms of researching illicit financial activities because of its inclusive and multidisciplinary research and its engagement with real-world situations.

However, its normative agenda and its motivation to judge rather than explain can be tricky in researching illicit activities. Since illicit financial activities are complex processes, I argue that the main motivation to research these activities should explain them rather than judging. Once we understand these complex structures, it would be possible to focus on these processes and possible countermeasures and the discussion's normative side. Hence, I argue that the British school cannot be a starting point for researching illicit financial activities since it fails to understand the complexity of the structures and processes. Instead, it can be a supplementary school regarding countermeasures after the activities explored by other schools of thought.

On the other hand, Constructivist IPE, is the most suitable school of IPE to research illicit financial activities. Explaining why Constructivist IPE is the most suitable, I use Abdelal, Blyth and Parsons (2010)'s four paths: meaning, cognition, uncertainty, and subjectivity.

Abdelal, Blyth and Parsons (2010) argue that meaning is one of the key concepts to understand IPE because social identities are not categorical as mainstream IPE claims, and defining what is appropriate and legitimate is a result of the socialization of actors in the system. In that manner, I argue that countering funding terrorism can be explained better by the meaning concept in the constructivist IPE. For 
instance, the transformation of G8 on countering financing terrorism was a process. Technocrats and advisors of presidents of member states played a crucial role in this transformation. Consequently, the meaning of terrorism and G8 itself changed during the process that transformed G8 from an economic advisory platform to one for countering financing terrorism. In this process, debating terrorism (then acting against it) in a financial forum has become appropriate by advisors and foreign ministers' efforts. Likewise, the US and Russia sanctioned Saudi Arabia or Iraq because it was appropriate based on the new meaning of terrorism.

Abdelal, Blyth and Parsons (2010) also argue that human beings filter the information from the environment via heuristics and biases and social construction matters in terms of action. In other words, the way people interpret the world (cognition) and how they frame the issues are crucial. Cognition plays a critical role in understanding the PLO example. On the one hand, unlike in the US, the PLO was not recognized as a terrorist organization by the EU (Ehrenfeld, 2005: 8). On the other hand, the EU emphasizes the existence of mechanisms to identify financing terrorism, which is different than the US' perspective (Ehrenfeld, 2005: 16). Put differently, cognition plays a crucial role in defining financing terrorism and acting against it. Since the EU interpreted PA as a legitimate authority rather than a terrorist organization, funding PA was not a problem and not considered financing terrorism.

Abdelal, Blyth and Parsons (2010) further argue that certain actors are uncertain about what to do until they invent a new framework for action and eliminate the uncertainty. For instance, uncertainty played a crucial role in understanding the example of the hawala system above. Even though there was concrete evidence regarding the use of alternative remittance systems, particularly hawala, in recent cases of terrorism, states did not consider regulating this system until the FATF published a report on this issue (Biersteker and Eckert, 2007: 5). States and financial actors started to hedge against the hawala system after the FATF eliminated the uncertainty about the hawala system. In other words, there was uncertainty concerning the hawala system until a new framework for action was invented or it was provided with social 
constructs, as Abdelal, Blyth and Parsons (2010) argue. Uncertainty prevented financial actors' actions until the hawala system's status was changed by social constructions, even though this system was a crucial tool of funding terrorism.

Abdelal, Blyth and Parsons (2010) argue that the agents and their powers of the agency are made possible by the particular discourse in which actors place themselves or are placed within. For instance, the US was not funding the YPG at the beginning of the Syrian civil war. However, after the expansion of the so-called Islamic State and other extremist Islamic groups in the region, the discourse regarding YPG dramatically changed. From a terrorist organization, YPG has become the only secular militia force in the region in the US's eye, which led to its legitimization and resulted in US financial aid to YPG. Simply put, the US funded the YPG not because of material interests but by coconstitution.

As Constructivist IPE's analyses on financing terrorism show, it is the most suitable approach to understand illicit financial activities. As with financing terrorism, it is also the best approach to study another catastrophic beast in the global financial system, tax havens. While tax havens are instrumental for tax avoidance for multinational corporations, the lack of transparency makes them attractive to transnational crime networks and terrorist organizations, as well. The use of tax havens in money laundering and financing terrorism was examined by several scholars (Johnson, 2002; Masciandaro and Portolana, 2003; Van Fossen, 2003; Fitzgerald, 2004; Gallant, 2007). Studies point out that secrecy in tax havens is the main facilitator of financing illicit activities. Because of strict secrecy and multilayering, it is almost impossible to track these illegal money flows. Therefore, tax havens pose a vital threat to not only financial security but also international security. Thus, countering this threat is also essential.

Notwithstanding that fighting with tax havens is a long run, it is essential to note that it boosted in the early 2000s, specifically after 9/11. There were some efforts to prevent tax havens even before 9/11, though. In 2000, international organizations began blacklisting offshore centers and threatening them with sanctions (Van Fossen, 
2003: 254). The Financial Stability Forum, then became the Financial Stability Board, was founded in 1999 and is an example of international organizations that acted before 9/11. In April 2000, the forum released their assessments of forty-two jurisdictions which they classified as offshore financial centers (Masciandaro and Portolana, 2003: 342). Another international organization, namely, the Organization for Economic Cooperation and Development (OECD), also published a report on tax havens in 2000 and blacklisted offshore centers. In addition, the FATF created a money-laundering blacklist in 2000 (Masciandaro and Portolana, 2003: 341). Also, a group of twelve leading international banks agreed to the Wolfsberg Principles for selfregulation, which were established with Transparency International's assistance and focused on increased due diligence on banks (Fitzgerald, 2004: 390).

9/11 was a game-changer in fighting illicit activities in tax havens since it kick-started a new era of financial oversight (Winer and Roule, 2002: 88; Abadie and Gardeazabal, 2008: 1). After 9/11, American policymakers saw the terrorist attacks as a new opportunity to connect the dangers posed by offshore centers with the funding of illegal organizations and threats to national security, and the American media portrayed offshore centers as havens for terrorists and other criminals (Van Fossen, 2003: 264). As Biersteker and Eckert (2007: 3) assert, most of the financial policy responses after $9 / 11$ focused on formal sector financial controls, harmonizing governmental policy, and improving financial regulatory capacity throughout the world.

Within three months after the 9/11, nearly two hundred countries joined a global effort to block terrorist funding, one hundred and thirty-nine of them blocked access to funds, and the US government took action by freezing terrorists' assets, setting up the Foreign Asset Tracking Center, and establishing Operation Green Quest (Johnson, 2002: 345). As a response to 9/11, the wider G20 group adopted an action plan to increase cooperation among states and international institutions to adopt necessary measures to limit international terrorist funding after the UN Security Council Resolution 1373 (Fitzgerald, 2004: 395). 
Despite the international cooperation efforts and the US's leading role in fighting financing terrorism through tax havens, it is hard to say that the fight was successful or over (Napoleoni, 2007: 175). While there is not a single answer for the reason of the failure to counter financing terrorism via tax havens, I argue that this process may make more sense with Constructivist IPE lenses.

In terms of fighting money laundering and financing terrorism in tax havens, 9/11 played a crucial role because it helped change tax havens' meaning. Before 9/11, tax havens were inappropriate, but their meaning is usually related only to tax evasions; therefore, most states chose to turn a blind eye to them. However, the meaning of tax havens changed after $9 / 11$ by socialization. Perceptions on tax havens exceeded tax evasions and started to become related to financing terrorism that hit the heart of the Western civilization. Hence, the countries that turned a blind eye to tax havens before 9/11 changed their attitudes and joined coordinated efforts to prevent financing terrorism in tax havens within three months after 9/11 (Johnson, 2002: 345).

Due to the US's efforts, the FATF blacklisted some countries and imposed sanctions on them after 9/11. However, these countries' responses varied, I argue, as a result of cognition. Caribbean nations accused the large industrial nations of unfairly targeting the small Caribbean islands despite their repeated denials that they were not involved in illicit activities and accused larger countries involved in illicit financial activities, but only small nations are facing sanctions (Johnson, 2002: 349). The responses of the Pacific Islands' also varied. Many small island economies are highly dependent upon offshore finance. In some cases, ninety percent of government revenues derive from offshore activities (Hampton and Christensen, 2002: 1657). Hence, although most of the small countries in the Pacific have been blacklisted, only Niue and Cook Island have responded positively, and another country, Vanuatu, has stated explicitly that it will not conform to the requirements when OECD members do not face the same restrictions (Johnson, 2002: 349). As the variation of responses from different countries shows us, cognition played a crucial role in fighting illicit tax havens' activities. 
The international community did not take any concrete action against tax havens until 9/11 because there was a quiet uncertainty about how to act. After 9/11, however, they acted because there was a new framework for action: fighting against tax havens because of funding terrorism. Before 9/11, there was a clash in the tax haven discourse between states and a clash within states, with private citizens seeking the advantages of the tax havens which their state opposes to (Gallant, 2007: 456). States have often hesitated to equip themselves with restrictive financial legislation because the law can become an obstacle to the free flow of capital (Sorel, 2003: 377). However, the inclusion of terrorism in tax haven discourse created more incentive to thoroughly investigate the international financial sphere and develop concrete strategies against tax havens (Gallant, 2007: 457).

In sum, states and the international community's socialization after 9/11 changed the status of tax havens. Before 9/11, tax havens were not appropriate, but it was usually related only to tax evasions whereas it became a part of financing terrorism discussions after 9/11. Thereby, financial institutions began worrying about countering money laundering and terrorism financing after 9/11 (Hardouin, 2009: 203). For instance, the International Monetary Fund (IMF) and the World Bank pledged to counter financing terrorism (Winer and Roule, 2002: 92). Even though fighting money laundering and funding terrorism gained more importance after $9 / 11$, doing it through tax havens almost failed because of different cognitions. Since states framed the issue differently and acted accordingly, a concrete and effective global strategy could not be implemented.

As shown, Constructivist IPE is the most suitable school of IPE to research financing terrorism and tax havens. Thanks to its key concepts, it provides more fruitful analyses on illicit financial activities. To prove this argument further, a case study is provided below.

\section{A Case Study: The Transformation of the Status of Tax Havens after $\mathbf{9} / 11$}

As stressed above, the status of tax havens changed after 9/11. Before the 9/11, tax havens were not appropriate, but it was usually related only to tax evasions while perceptions on tax havens changed 
and they started to associate with financing terrorism. This was a game-changer regarding the status of tax havens. With the Global War on Terror under the US's leadership, tax havens and their role in funding terrorism were questioned. However, this shift in perception has also changed after the first years of the Global War on Terror. Even though tax havens are still at the heart of money laundering activities and funding terrorism, the decline in the US efforts to fight terrorism affected their status again.

To show the shifts in tax havens' status after 9/11, I conducted a discourse analysis using the LexisNexis Academia database. I created three timelines, namely from 1995 to 2000, from 2001 to 2006, and from 2006 to 2011, and picked two Western countries, namely the United States and the United Kingdom. I also picked three major newspapers for each country. For the US, three newspapers are The New York Times, The Washington Post, and USA Today. On the other hand, for the UK, three newspapers are The Guardian, The Independent, and The Times. For these six newspapers, I counted how many times an article on tax havens was published in three different timelines. Also, I counted how many times American or British newspapers in general published articles that include both tax havens and terrorism in these three different timelines. The results are as follows.

In the US case, there were one hundred and forty-three news stories related to tax havens between 1995 and 2000. There were nine specific articles related to tax havens in The New York Times, eight specific articles in The Washington Post, and one specific article in USA Today. Between 2001 and 2006, there were three hundred and seventy-four articles related to tax havens. There were twenty-eight specific articles related to tax havens in The New York Times, twenty-two specific articles in The Washington Post, and four specific articles in USA Today. Between 2006 and 2011, on the other hand, there were two hundred and thirteen news stories related to tax havens. There were seven specific articles related to tax havens in The New York Times, eight specific articles in The Washington Post, and one specific article in USA Today. 
The results show two major shifts in the status of tax havens. The first shift took place after 9/11. According to results, before 9/11, namely the era between 1995 and 2000, tax havens were not crucial or newsworthy. One hundred forty-three articles in total and eighteen articles in the three major newspapers were published. However, after 9/11, namely the era between 2001-2006, there was a huge shift in interest in tax havens because I argue that the status of tax havens changed, and tax havens started to associate with financing terrorism. Three hundred seventy-four articles in total in the US media and fiftyfour articles in the three major newspapers were published. As a result of the association between tax havens and funding, terrorism affected the discourse of tax havens.

The second shift was related to the relative decline in the US efforts in terms of fighting terrorism. From 2001 to 2006, the Global War on Terror was at its peak under the Bush administration. The invasion of Afghanistan and Iraq happened during that era. However, among others, failures and the change in the US's public opinion in terms of these operations affected the discourse of the Global War on Terror. Accordingly, the interest in tax havens dramatically declined in the era between 2006 and 2011. Tax havens again started to associate with tax evasions rather than funding terrorism. During that era, only seven specific articles related to tax havens were published in The New York Times, eight were published in The Washington Post, and only one was published in USA Today. As results show, the discourse of tax havens has dramatically changed in the US and affected the status of tax havens.

In the UK case, there were two hundred and thirty-two news stories related to tax havens between 2000 and 2006. There were forty-three specific articles related to tax havens in The Guardian, twenty-one specific articles in the Independent, and seventeen articles in The Times. Between 2006 and 2011, there were two hundred and eightythree articles related to tax havens. There were eighty-eight specific articles related to tax havens in The Guardian, thirty-five specific articles in The Independent, and fourteen specific articles in The Times. 
The results show a significant shift in the status of tax havens that occurred after the relative decline in the US efforts in terms of fighting terrorism. Between 2001 and 2006, under the US's leadership against global terrorism, there were two hundred and thirty-two articles. However, with the relative decline in the US efforts, tax havens' status and British perception of tax havens have changed. Unlike the US, the interest in tax havens increased in the era between 2006 and 2011. Two hundred and eighty-three articles related to tax havens were published, whereas the number of published journals regarding tax havens was two hundred and thirty-two in the era between 2001 and 2006. Among others, I argue that the decline in the US efforts affected the British discourse regarding tax havens. With the decline in US efforts, the UK might have considered itself against global terrorism.

Besides the US and UK's surveys, I also conducted a more specific analysis covering these two countries. More specifically, I have counted the articles that specifically covers the relation between funding terrorism and tax havens in these three eras. The results are coherent with the individual results of the countries. In the era between 1995 and 2000, only two articles cover the relationship between funding terrorism and tax havens. Between 2001 and 2006, twentyeight specific articles were published, whereas twenty-two specific articles were published between 2006 and 2011.

Table 1: Discourse Analysis, the US (1995-2011)

\begin{tabular}{lccc}
\hline & $\mathbf{1 9 9 5 - 2 0 0 0}$ & $\mathbf{2 0 0 1 - 2 0 0 6}$ & $\mathbf{2 0 0 6 - 2 0 1 1}$ \\
\hline The New York Times & 9 & 28 & 7 \\
The Washington Post & 8 & 22 & 8 \\
USA Today & 1 & 4 & 1 \\
\hline Total & 143 & 374 & 213 \\
\hline
\end{tabular}

Table 2: Discourse Analysis, the UK (2001-2011)

\begin{tabular}{lcc}
\hline & $\mathbf{2 0 0 1 - 2 0 0 6}$ & $\mathbf{2 0 0 6 - 2 0 1 1}$ \\
\hline The Guardian & 43 & 88 \\
The Independent & 21 & 35 \\
The Times & 17 & 14 \\
\hline Total & 232 & 283 \\
\hline
\end{tabular}

As the analysis shows, the status of tax havens changed between 1995 and 2011. Before 9/11, tax havens were not associated with 
funding terrorism. Since 9/11, with the association of funding terrorism and tax havens, the discourse has changed. Also, after the relative decline in the US efforts against terrorism, the UK's tax havens' discourse has changed. It is important to note that it is almost impossible to understand tax havens, financing terrorism, and fighting against them without knowing these changes and focusing only on material interests. In that manner, American IPE, with its strict focus on material issues in the Anglosphere and strict methodology, cannot adequately analyze the changing status of tax havens after 9/11. Likewise, instead of focusing facts of terrorism financing and changing status of tax havens, the focus of British school on "financial oppression" to Pacific countries which are offshore centers will not provide fruitful analyses regarding financing terrorism, money laundering and tax havens.

With its key concepts to explain the analysis of the elements of financing terrorism, Constructivist IPE is the most suitable approach to research illicit financial activities. Thanks to its key concepts, Constructivist IPE can capture the dynamism of the status of tax havens. As the discourse analysis shows, the meaning of the tax havens dramatically changed after $9 / 11$. While tax havens were associated with tax evasions, they started to be perceived as financial hubs of terrorist organizations. Furthermore, even though their meaning changed due to US leadership, states' response to this shift varied due to the cognition of the tax havens. However, once the new framework of the status of tax havens was established, states formulated their policy according to the new framework. A closer examination of states' responses to this shift also illuminates the success of Constructivist explanations. US and UK's perceptions on tax havens followed a similar pattern after $9 / 11$. While tax havens were associated with financing terrorism after $9 / 11$, they were portrayed as hubs for tax evasions after 2006.

\section{Conclusion}

International Political Economy studies do not interest in illicit financial activities as much as they should. Since there is relatively less attention to illicit financial activities in the IPE studies, it is mostly 
ambiguous how to study these illicit activities. The existing literature consists of either security-focused studies which are not highly related to the economic perspective and background of the issue or narrowly focused on countermeasures of illicit financial activities and mostly against terrorist financing. Hence, it is imperative to find more suitable ways to research illicit financial activities.

Terrorist organizations, as actors of the international political and economic system, launder their money in tax havens to finance their organizations and attacks as a result of financial liberalization and deregulation after the 1990s. I argue that the most suitable school of IPE to research these illicit activities of terrorist organizations is Constructivist IPE. American IPE's materialistic nature and statecentric approach miss the important features/relations of these illicit activities because they neither are materialistic nor include only states. On the other hand, the British school is more suitable than the American IPE in researching illicit financial activities because of its inclusive and multidisciplinary research and its engagement with realworld situations. However, its normative agenda and its motivation to judge rather than explain can be tricky in researching illicit activities. Since illicit financial activities are complex processes, I argue that the main motivation to study these activities should focus on explaining them rather than judge. Once we understand these complex structures, we can focus on these processes and possible countermeasures and the discussion's normative side. Hence, British school, I argue, is not a good start to research illicit financial activities. It can be a supplementary school, however, after exploring these activities.

Constructivist IPE is the most suitable school of IPE to research illicit activities because of its dynamism and concepts, namely meaning, cognition, uncertainty, and subjectivity. With these four concepts, researchers can conduct more detailed and more fruitful analyses regarding illicit financial activities. A case study of 9/11 and tax havens shows us how Constructivist IPE is more suitable for describing and analyzing illicit financial activities at both national and international levels. 
It is important to note that I do not argue that Constructivist IPE is superior or better than other major schools of IPE. However, Constructivist IPE is the most suitable school to research illicit financial activities because of its dynamic concepts. It is also important to note that I do not claim all these illicit financial activities are independent of interest. Interest also plays a crucial role. Yet, even exploring the interest in these illicit financial activities is more meaningful with Constructivist lenses because interests are mainly shaped by how actors of the system frame them.

Last but not least, there should be more research on illicit financial activities in the IPE studies. These studies should focus on individual beasts of the system, namely, money laundering, funding terrorism, and tax havens and the adverse effects of these beasts on the international political and economic system in general. Also, these studies should benefit from Constructivist IPE to explore these activities. In doing so, the research on the issue can help to provide a comprehensive understanding of the problem and formulate more coherent countermeasures.

Ethics Statement: The author declare that ethical rules are followed in all preparation processes of this study. In case of detection of a contrary situation, BIİBFAD Journal does not have any responsibility and all responsibility belongs to the authors of the study

Acknowledgement: I would like to thank the Editorial Board of BİBFAD Journal for their intense interest and efforts and the referees for their contribution.

\section{References}

Abadie, A., \& Gardeazabal, J. (2008). Terrorism and the world economy. European Economic Review, 52(1), 1-27.

Abdelal, R., Blyth, M., \& Parsons, C. (Eds.). (2010). Constructing the international economy. Cornell University Press.

Abuza, Z. (2003). Funding terrorism in Southeast Asia: the financial network of Al Qaeda and Jemaah Islamiya. Contemporary Southeast Asia, 25(2), 169-199. 
Al, A. (2015). Politika-ekonomi kesişmesi: yeni bir bilim dalı olarak uluslararası politik ekonomi. İstanbul Gelişim Üniversitesi Sosyal Bilimler Dergisi, 2(1), 143-159.

Belelieu, A. (2002). The G8 and terrorism: What role can the G8 play in the 21st century. G8 Governance, 8, 1-35.

Berry, C. (2020). The Sick Man of IPE: the British School. In The Routledge Handbook to Global Political Economy (pp. 29-42). Routledge.

Biersteker, T. J., \& Eckert, S. E. (Eds.). (2007). Countering the financing of terrorism. Routledge.

Bindner, L. (2016). Illicit trade and terrorism financing. Centre d'Analyse du Terrorisme (CAT).

Bowers, C.B. (2008). Hawala, money laundering, and terrorism finance: Mirco-lending as an end to illicit remittance. Denv. J. Int'l L. \& Pol'y, 37, 379.

Clunan, A.L. (2006). The fight against terrorist financing. Political Science Quarterly, 121(4), 569-596.

Cohen, B.J. (2014). Advanced Introduction to International Political Economy. Edward Elgar Publishing.

Dean, A., Thompson, E., \& Keatinge, T. (2013). Draining the ocean to catch one type of fish: Evaluating the effectiveness of the global counter-terrorism financing regime. Perspectives on Terrorism, 7(4), 62-78.

Deciancio, M., \& Quiliconi, C. (2020). Widening the 'Global Conversation': Highlighting the voices of IPE in the Global South. All Azimuth: A Journal of Foreign Policy and Peace, 9(2), 249-266.

Desai, M. A., Foley, C. F., \& Hines, J. R. (2006). The demand for tax haven operations. Journal of Public economics, 90(3), 513-531.

Dishman, C. (2001). Terrorism, crime, and transformation. Studies in Conflict and Terrorism, 24(1), 43-58. 
Donohue, L. (2006). Anti-terrorist finance in the United Kingdom and United States. Michigan Journal of International Law, 27, 303-435.

Ehrenfeld, R. (2002). Funding Terrorism: sources and methods. In Workshop held at Los Alamos National Laboratory March (Vol. 25, No. 29).

Ehrenfeld, R. (2005). Funding Evil: How Terrorism is Financed--and how to Stop it. Bonus Books, Inc.

Farrell, H., \& Finnemore, M. (2009). Ontology, methodology, and causation in the American school of international political economy. Review of International Political Economy, 16(1), 58-71.

FBI. (2016).

Terrorism.

Retrieved

from.

https://www.fbi.gov/investigate/terrorism

Access: $10 / 02 / 21$

Fitzgerald, V. (2004). Global financial information, compliance incentives and terrorist funding. European Journal of Political Economy, 20(2), 387-401.

Freeman, M. (2011). The sources of terrorist financing: theory and typology. Studies in Conflict \& Terrorism, 34(6), 461-475.

Freeman, M., \& Ruehsen, M. (2013). Terrorism financing methods: An overview. Perspectives on Terrorism, 7(4), 5-26.

Germain, R.D. (2009). The 'American'school of IPE? A dissenting view. Review of International Political Economy, 16(1), 95-105.

Giraldo, J., Trinkunas, H., \& Zellen, B. (2005). Terrorism Financing and State Responses in Comparative Perspective. Center for Contemporary Conflict (ed.),(Monterey, 2004), 174.

Hampton, M.P., \& Christensen, J. (2002). Offshore pariahs? Small island economies, tax havens, and the re-configuration of global finance. World Development, 30(9), 1657-1673.

Hardouin, P. (2009). Banks governance and public-private partnership in preventing and confronting organized crime, corruption and terrorism financing. Journal of Financial Crime, 16(3), 199-209. 
Hira, A., Murata, B., \& Monson, S. (2019). Regulatory mayhem in offshore finance: What the Panama papers reveal. In The Failure of Financial Regulation (pp. 191-232). Palgrave Macmillan, Cham.

Hobson, J.M. (2019). What's at Stake in Doing (Critical) IR/IPE Historiography? The Imperative of Critical Historiography. In Historiographical Investigations in International Relations (pp. 149-169). Palgrave Macmillan, Cham.

IMF (2016). Anti-money laundering/combating the financing of terrorismtopics. $\quad$ Retrieved from. https://www.imf.org/external/np/leg/amlcft/eng/aml1.ht m Access: 10/02/21

Jamwal, N. S. (2002). Hawala-the invisible financing system of terrorism. Strategic Analysis, 26(2), 181-198.

Johnson, J. (2002). 11th September and revelations from the Enron collapse add to the mounting pressure on offshore financial centres. Journal of Financial Regulation and Compliance, 10(4), 341354.

Jost, P.M., \& Sandhu, H.S. (2003). The hawala alternative remittance system and its role in money laundering. Interpol.

Levitt, M.A. (2002). The political economy of Middle East terrorism. Middle East Review of International Affairs, 6(4), 49-65.

Li, Q., \& Schaub, D. (2004). Economic globalization and transnational terrorism a pooled time-series analysis. Journal of Conflict Resolution, 48(2), 230-258.

Maliniak, D., \& Tierney, M.J. (2009). The American school of IPE. Review of International Political Economy, 16(1), 6-33.

Masciandaro, D., \& Portolano, A. (2003). It takes two to Tango: International financial regulation and offshore centres. Journal of Money Laundering Control, 6(4), 311-330.

McCulloch, J., \& Pickering, S. (2005). Suppressing the financing of terrorism proliferating state crime, eroding censure and 
extending neo-colonialism. British Journal of Criminology, 45(4), 470-486.

Gallant, M.M. (2007). Tax and terrorism: a new partnership?. Journal of Financial Crime, 14(4), 453-459.

Napoleoni, L. (2007). Terrorism financing in Europe. Journal of Middle Eastern Geopolitics, 1(2), 171-184.

OECD (2019), Money Laundering and Terrorist Financing Awareness Handbook for Tax Examiners and Tax Auditors, OECD, Paris. Retrieved from www.oecd.org/tax/crime/money-launderingand-terrorist-financing-awareness-handbook-for-taxexaminers-and-taxauditors.pdf Access: 07/07/21

Raphaeli, N. (2003). Financing of terrorism: sources, methods, and channels. Terrorism and Political Violence, 15(4), 59-82.

Roth, M.P., \& Sever, M. (2007). The Kurdish Workers Party (PKK) as criminal syndicate: Funding terrorism through organized crime, a case study. Studies in Conflict \& Terrorism, 30(10), 901920.

Rudner, M. (2006). Using financial intelligence against the funding of terrorism. International Journal of Intelligence and CounterIntelligence, 19(1), 32-58.

Rudner, M. (2010). Hizbullah terrorism finance: Fund-raising and money-laundering. Studies in Conflict $\mathcal{E}$ Terrorism, 33(8), 700715 .

Seabrooke, L., \& Young, K.L. (2017). The networks and niches of international political economy. Review of International Political Economy, 24(2), 288-331.

Shaxson, N. (2011). Explainer: what is a tax haven?. The Guardian. Retrieved from. https://www.theguardian.com/business/2011/jan/09/expla iner-what-is-tax-haven Access: 10/02/21

Shelley, L. (2004). Unholy trinity: transnational crime, corruption, and terrorism. Brown J. World Aff., 11, 101. 
Sorel, J.M. (2003). Some questions about the definition of terrorism and the fight against its financing. European Journal of International Law, 14(2), 365-378.

Stein, A. \& Foley, M. (2016). The YPG-PKK Connection. Retrieved from http://www.atlanticcouncil.org/blogs/menasource/the-ypgpkk-connection Access: 10/02/21

Thies, C.G., \& Wehner, L.E. (2019). The role of role theory in international political economy. Cambridge Review of International Affairs, 32(6), 712-733.

Unger, B. (2017). Offshore activities and money laundering: recent findings and challenges. Policy Department A: Economic and Scientific Policy, European Parliament.

Van Fossen, A.B. (2003). Money laundering, global financial instability, and tax havens in the Pacific Islands. The Contemporary Pacific, 15(2), 237-275.

Veseth, M. (2002). What is international political economy. Retrieved from http:/ / eolss.net/Sample-Chapters/C14/E1-35-02.pdf Access: $07 / 07 / 21$

Walzenbach, G. (2016). Global political economy. Retrieved from https:/ / www.e-ir.info/2016/12/29/global-politicaleconomy/ Access: 07/07/21

Wang, Q.K., \& Blyth, M. (2013). Constructivism and the study of international political economy in China. Review of International Political Economy, 20(6), 1276-1299.

Winer, J.M., \& Roule, T.J. (2002). Fighting terrorist finance. Survival, 44(3), 87-104. 